\title{
Beta $_{3}$-Adrenergic Receptor Gene Studies in Patients With Prader-Willi Syndrome
}

\author{
Merlin G. Butler*, \\ Departments of Pediatrics, Pathology and Orthopedics, Vanderbilt University Medical Center, \\ Nashville, Tennessee \\ Lora K. Hedges, and \\ Departments of Pediatrics and Orthopedics, Vanderbilt University Medical Center, Nashville, \\ Tennessee
}

Ken S. Babe Jr.

Department of Medicine, Vanderbilt University Medical Center, Nashville, Tennessee

\section{To the Editor}

Prader-Willi syndrome (PWS) is characterized by infantile hypotonia, early onset childhood obesity, hypogonadism, hyperphagia, small hands and feet, mental deficiency, a characteristic face, and a paternal deletion of 15q11q13 or maternal uniparental disomy of chromosome 15 [Cassidy, 1984; Butler et al., 1986; Butler, 1990; Mascari et al., 1992]. PWS is the most common genetic cause of marked obesity with an incidence of 1 per 15,000 [Butler, 1990].

Recently, investigators have identified candidate genes involved with the regulation of storage and mobilization of energy in adipose tissue. One such candidate is the beta $3^{-}$ adrenergic receptor gene which is expressed in adipose tissue and involved in the regulation of lipolysis, thermogenesis and energy expenditure [Emorine et al., 1989; Kadowaki et al., 1955; Clement et al., 1995]. A beta3-adrenergic receptor gene mutation (Trp64Arg) was recently reported by Clement et al. [1995] to be more frequent in obese individuals with an increased capacity to gain weight. Kadowaki et al. [1995] reported in Japanese subjects that body mass index was significantly higher in subjects homozygous for the Trp64Arg mutation than in those homozygous for the normal alleles. The resting metabolic rate in subjects with PWS is decreased [Schoeller et al., 1988; Hill et al., 1990] and the cause of this abnormal rate can not be entirely explained by a decreased fat free mass. Therefore, our study was undertaken to identify if the Trp64Arg mutation of the beta 3 -adrenergic receptor gene plays any role in the obesity or degree of fatness in subjects with PWS. Herein, we report data from our betaz-adrenergic receptor gene mutation study of 30 subjects with PWS.

*Correspondence to: Merlin G. Butler, M.D., Ph.D., Division of Genetics, Department of Pediatrics, Vanderbilt University, School of Medicine, DD-2205 Medical Center North, Nashville, TN 37232-2578. 
Thirty Caucasian patients ( 15 males; 15 females), meeting the diagnostic criteria for PraderWilli syndrome reported by Holm et al. [1993], had an average age ( \pm S.D.) of 12.5 years $( \pm 8.6)$ and an age range of 1 to 35 years. Seventeen of these 30 subjects with PWS had the 15q11q13 deletion, detected by high resolution chromosome analysis and confirmed by fluorescence in situ hybridization with 15q11q13 probes (e.g., SNRPN), 7 subjects with PWS had maternal uniparental disomy of chromosome 15 determined by molecular genetic studies with polymerase chain reaction using DNA microsatellites or markers from chromosome -15 , and 3 patients had reciprocal or Robertsonian translocations involving chromosome 15. Normal chromosomes were found in the remaining 3 patients but no further genetic testing was possible due to either a small quantity of DNA or lack of parental DNA.

Height and weight were obtained and body mass index (BMI) calculated (weight in kilograms divided by the height in meters squared). The average ( \pm S.D.) for height was $127.8 \mathrm{~cm}( \pm 24.8)$ and $52.2 \mathrm{~kg}( \pm 32.0)$ for weight. The average ( \pm S.D.) for BMI was 29.0 $( \pm 10.5)$. Eighteen of the 30 PWS individuals were judged to have obesity (BMI $\geq 27$ for adults and BMI $\geq 24$ for children) while 4 of the 30 PWS patients had morbid obesity (BMI 240) [Klish, 1995]. Individuals with PWS but without obesity were either under diet control or studied during early childhood before the onset of obesity by weight per height criteria.

Blood samples were obtained from each subject and genomic DNA extracted routinely [Butler et al., 1993] and polymerase chain reaction (PCR) amplification performed. Forward (5' CCAGTGGGCTGCCAGGGG3') and reverse (5'GCCAGTGGCGCCCAACGG3') oligonucleotide primers were used for the beta $3^{-}$-adrenergic receptor gene sequence encoding amino acid residues 27 to 110 including position 64 [Clement et al., 1995]. The Trp64Arg mutation is detectable by restriction-fragment-length polymorphisms with the use of the endonuclease, BstNI, and the digested 248-bp amplified PCR product as described by Clement et al. [1995]. BstNI digested fragments produced from the normal receptor genes and separated by gel electrophoresis produced a 97-bp fragment and a double of 64 and 61 bp which are non-resolvable; heterozygotes have a 158-bp band, the 97-bp band and the 64bp and 61-bp doublet; homozygous mutants have a 158-bp band and the 64-bp band. All digests have 15-bp and 11-bp fragments.

The prevalence of the Trp64Arg mutation of the beta 3 -adrenergic receptor gene was determined in our patients with Prader-Willi syndrome and compared with reported control data [Clement et al., 1995]. Of our 30 subjects with PWS, one subject (1-year-old female with BMI of 17.4) had a homozygous mutation while all other subjects with PWS showed normal alleles with no Trp64Arg mutations. Thus, our individuals with PWS and obesity, including those with morbid obesity, did not show the mutation.

Figure 1 shows PCR amplification and polyacrylamide electrophoretic analysis of the betaadrenergic receptor gene encompassing the mutation from a representative sample of control and PWS subjects including the individual homozygous for the mutation.

The prevalence of the beta 3 -adrenergic receptor gene mutation in our subjects with PWS was 0.03 compared with the reported frequency of 0.08 and 0.10 , respectively, for morbidly obese and normal subjects [Clement et al., 1995]. Our gene mutation data were not 
significantly different (chi-square value $=1.86 ; P>0.05$ ) in subjects with PWS or morbidly obese and normal Caucasian subjects reported by Clement et al. [1995].

\section{Acknowledgments}

Contract grant sponsor: National Institute of Child Health and Human Development; Contract grant number: PO1HD30329.

We thank Lisa Woods for expert preparation of the manuscript.

\section{References}

Butler MG. Prader-Willi syndrome: Current understanding of cause and diagnosis. Am J Med Genet. 1990; 35:319-332. [PubMed: 2309779]

Butler MG, Meaney FJ, Palmer CG. Clinical and cytogenetic survey of 39 individuals with PraderWilli syndrome. Am J Med Genet. 1986; 23:793-809. [PubMed: 3953677]

Butler MG, Dahir GA, Schwartz HS. Molecular analysis of transforming growth factor beta in giant cell tumor of bone. Cancer Genet Cytogenet. 1993; 66:108-12. [PubMed: 8500096]

Cassidy SB. Prader-Willi syndrome. Curr Prob Pediat. 1984; 14:1-55.

Clement K, Vaisse C, Manning B, Basdevant A, Guy-Grand B, Ruiz J, Silver K, Shuldiner A, Froguel $\mathrm{P}$, Strosberg AD. Genetic variation in the $\mathrm{B}_{3}$-adrenergic receptor and an increased capacity to gain weight in patients with morbid obesity. New Eng J Med. 1995; 333:352-354. [PubMed: 7609752]

Emorine LJ, Marullo S, Briend-Sutren M-M. Molecular characterization of the human beta3adrenergic receptor. Science. 1989; 245:1118-21. [PubMed: 2570461]

Hill JO, Kaler M, Spetalnick B, Reed G, Butler MG. Resting metabolic rate in Prader-Willi syndrome. Dysmorph Clin Genet. 1990; 4:27-32.

Holm VA, Cassidy SB, Butler MG, Hanchette JM, Geenswag LR, Whitman BY, Greenberg F. Diagnostic criteria for Prader-Willi syndrome. Pediatrics. 1993; 91:398-402. [PubMed: 8424017]

Kadowaki H, Yasuda K, Iwamoto K, Otabe S, Shimokawa K, Silver K, Walston J, Yoshinaga H, Kosaka K, Yamada N, Saito Y, Hagura R, Akanuma Y, Shuldiner A, Yazaki Y, Kadowaki T. A mutation in the $\mathrm{B}_{3}$-adrenergic receptor gene is associated with obesity and hyper-insulinemia in Japanese subjects. Biochem Biophysic Res Comm. 1995; 2:555-560.

Klish WJ. Childhood obesity: Pathophysiology and treatment. Acta Paediatrica Japonica. 1995; 37:16. [PubMed: 7754750]

Mascari JF, Gottlieb W, Rogan PK, Butler MG, Weller DA, Armour JAL, Jeffreys RL, Ladda RL, Nicholls RD. The frequency of uniparental disomy in Prader-Willi syndrome. New Eng J Med. 1992; 326:1599-1607. [PubMed: 1584261]

Schoeller DA, Levitsky LL, Bandini LG, Dietz WW, Walczak A. Energy expenditure and body composition in Prader-Willi syndrome. Metabolism. 1988; 37:115-120. [PubMed: 3340003] 


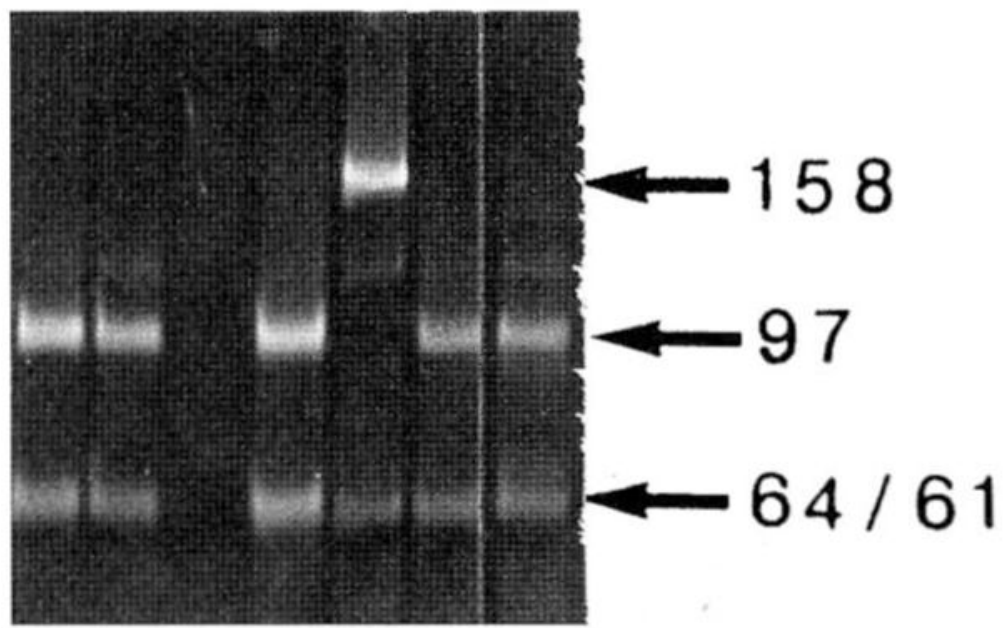

\section{7}

Fig. 1.

Representative polymerase chain reaction (PCR) amplification of the Trp64Arg mutation region of the beta 3 -adrenergic receptor gene from subjects with Prader-Willi syndrome (PWS) digested with BstNI, separated in agarose gel by electrophoresis and stained with ethidium bromide following the protocols described by Clement et al. [1995]. Lane 1: Subject with PWS showing a normal DNA pattern (97, 64/61). Lane 2: Subject with PWS showing a normal DNA pattern (97, 64/61). Lane 3: Blank lane with no PCR amplification. Lane 4: Subject with PWS showing a normal DNA pattern (97, 64/61). Lane 5: Subject with PWS showing a homozygous DNA mutation pattern $(158,64)$. Lane 6: Subject with PWS showing a normal DNA pattern (97, 64/61). Lane 7: Control subject without obesity showing a normal DNA pattern $(97,64 / 61)$. The 158-bp, 97-bp, and 64- and 61-bp doublet DNA fragments are designated by arrows. 